\title{
Synthesis, photophysical properties and DFT study of novel polycarbo-substituted quinazolines derived from the 2-aryl-6-bromo-4-chloro-8-iodoquinazolines
}

Hugues K. Paumo, ${ }^{1}$ Malose J. Mphahlele, ${ }^{1 *}$ Lydia Rhyman $^{2}$ and Ponnadurai Ramasami ${ }^{2}$

${ }^{1}$ Department of Chemistry, College of Science, Engineering and Technology, University of South Africa, P.O. Box 392, Pretoria 0003, South Africa.

${ }^{2}$ Computational Chemistry Group; Department of Chemistry, Faculty of Science, University of Mauritius, Réduit 80837, Mauritius.

*Author to whom correspondence should be addressed; E-Mail: mphahmj@unisa.ac.za; Tel. +2712-429-8805; Fax: +27-12-429-8549.

Abstract: A series of novel 2-aryl-6-bromo-4-chloro-8-iodoquinazolines were prepared and subjected to sequential two-step (Sonogashira and subsequent one-pot bis-Suzuki) and one-pot three-step Sonogashira cross-coupling reactions to afford unsymmetrical polycarbo-substituted quinazolines. Selectivity in the cross-coupling for these multihalogenated quinazolines was found to depend on both the intrinsic reactivity of the $\mathrm{Csp} \mathrm{p}^{2}$-halogen bond, which relates to the bond dissociation energy or bond strength and the electronic position of the halogen atom on the electron deficient scaffold (trend: $\mathrm{Csp}^{2}-\mathrm{I}>\mathrm{C}(4)-\mathrm{Cl}>\mathrm{Cs} p^{2}-\mathrm{Br}$ ). The electronic absorption and emission properties of the prepared polycarbo-substituted quinazolines were evaluated in solution by means of UV-Vis and emission spectroscopy in conjunction with density functional theory (DFT) method.

Keywords: 2-aryl-6-bromo-4-chloro-8-iodoquinazolines; cross-coupling reactions; polycarbosubstituted quinazolines; photophysical properties, DFT 


\section{Introduction}

Polycarbosubstitued quinazolines are sought-after nitrogen-based heterocycles due to their important biological activities such as potent epidermal growth factor receptor (EGFR) tyrosine kinase inhibition, ${ }^{1}$ liver X-receptor modulation ${ }^{2}$ and novel aurora A kinase inhibition. ${ }^{3}$ Interest in these compounds is not only limited to the synthesis or development of more diverse and complex bioactive derivatives for structure-activity relationship evaluations, but has since been extended to focus on their photophysical properties as potential fluorescence probes. ${ }^{4-9}$ Fluorescent carbosubstituted quinazolines such as the medicinally important Lapatinib, for example, functions as an environmentally responsive 'turn-on' fluorophore. ${ }^{8}$ Its analogue, (E)-6-(4-dimethylaminostyryl)- $N$ phenylquinazolin-4-amine, acts as a turn-on fluorescence kinase inhibitor in MCF7 cells. ${ }^{9}$ An alkynyl substituent at the C-4 or C-6 position of the 2-substituted quinazolines has previously been found to lead to enhanced EGFR or Aurora A kinase inhibition activity ${ }^{1}$ and intramolecular charge transfer properties. ${ }^{10,11}$ In view of the biological ${ }^{12}$ and fluorescence properties of 4/6-alkynylated quinazolines, ${ }^{10,11}$ we became interested in the synthesis of polycarbo-substituted derivatives in which the electron-deficient quinazoline framework is linked directly to the $\pi$-electron donating aryl groups at the 2-, 4- and 6-positions and through a $\pi$-conjugated spacer $(\mathrm{C}-\mathrm{C}$ triple bond) at the 8position for studies of photophysical properties. However, such unsymmetrical polycarbosubstituted quinazolines would not be easily accessible via the use of the known 2-aryl-4-chloro6,8-dibromoquinazolines ${ }^{10}$ and the analogous 6,8-dibromo-2,4-dichloroquinazoline, ${ }^{13,14}$ which have been found to undergo initial site-selective $\mathrm{C}(4)-\mathrm{Cl}$ substitution and subsequent cross-coupling at the 6- and 8-positions without selectivity. It has recently been demonstrated for the first time that $\mathrm{Cs} p^{2}-\mathrm{C} s p$ bond formation in the case of the chloro-iodo substituted quinazolines favours cross- 
coupling through the intrinsically more reactive $\mathrm{Csp}^{2}-\mathrm{I}$ bond instead of the highly activated C(4)-Cl bond. ${ }^{11}$ The observed reactivity of the $\mathrm{Csp} p^{2}-\mathrm{X}$ bond for multihalogenated quinazolines is in contrast to the generic order of reactivity for other polyhalogenated compounds, which allows selective coupling with iodides or bromides in the presence of chlorides. ${ }^{15}$ We envisioned that the bromoiodo-substituted 4-chloroquinazolines could serve as suitable substrates for sequential and/ or onepot multi-step cross-coupling reactions to afford unsymmetrical polycarbo-substituted quinazolines. Herein, we report the synthesis of the 2-aryl-6-bromo-4-chloro-8-iodoquinazolines and their transformation via sequential and one-pot multi-step cross-coupling reactions involving initial siteselective Sonogashira cross-coupling to incorporate the alkynyl group at the 8-position. The electronic absorption and emission properties of the resultant unsymmetrical polycarbo-substituted 8-alkynylquinazoline derivatives were evaluated in solution by means of Uv-Vis and emission spectroscopy in conjunction with density functional (DFT) method.

\section{Results and Discussion}

\subsection{Synthesis of 2-aryl-6-bromo-4-chloro-8-iodoquinzolines}

The first task in this investigation was to prepare the 2-aryl-6-bromo-8-iodoquinazolin-4(3H)ones required as substrates for phosphorus oxychloride-promoted aromatization to afford the requisite 2-aryl-6-bromo-4-chloro-8-iodoquinazolines. Access to the dihalogenated quinazolin$4(3 H)$-ones, in turn, required the use of 2-amino-5-bromo-3-iodobenzamide as a precursor for cyclocondensation with benzaldehyde derivatives. Recourse to the literature revealed that 2-amino5-bromobenzamide has been prepared in high yield from anthranilamide before, ${ }^{16}$ however, it has not been subjected to further halogenation to afford the corresponding mixed 3,5-dihalogenated 2- 
aminobenzamides. ${ }^{17}$ The analogous 2-amino-6,8-dibromobenzamide, on the other hand, has also been prepared in high yield from anthranilamide before. ${ }^{10} 2$-Aminobenzamide 1 was subjected to $N$ bromosuccimide in acetonitrile at room temperature to afford 2-amino-5-bromobenzamide 2, which in turn, was reacted with $\mathrm{N}$-iodosuccinimide in acetic acid at r.t. to afford 2-amino-5-bromo-3iodobenzamide 3 (Scheme 1).

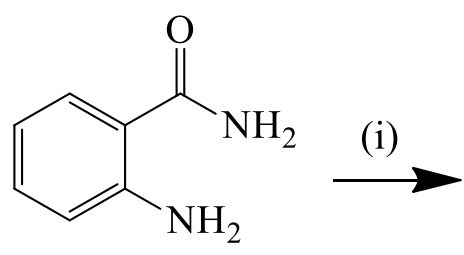

1<smiles>NC(=O)c1cc(Br)ccc1N</smiles>

$2(93 \%)$ (ii)<smiles>NC(=O)c1cc(Br)cc(I)c1N</smiles>

$3(88 \%)$

Reagents and conditions: (i) NBS, $\mathrm{CH}_{3} \mathrm{CN}$, r.t., $0.5 \mathrm{~h}$ (2); (ii) NIS, AcOH, r.t., $1 \mathrm{~h} \mathrm{(3)}$

Scheme 1: Sequential halogenation of 2-aminobenzamide to afford $\mathbf{2}$ and $\mathbf{3}$

We then exploited the combined electrophilic and oxidative properties of iodine in ethanol under reflux to effect the direct one-pot cyclocondensation of $\mathbf{3}$ with benzaldehyde derivatives and subsequent dehydrogenation of the incipient $4(1 H)$-oxo intermediates to afford novel potentially tautomeric 2-aryl-6-bromo-8-iodoquinazolin-4(3H)-ones 4a-d (Scheme 2). The resultant solid products, which were purified by recrystallization without the need for column chromatography were characterized through NMR $\left({ }^{1} \mathrm{H}\right.$ and $\left.{ }^{13} \mathrm{C}\right)$ spectroscopy and their 4-oxo- $N-(3 H)$ nature was also confirmed by IR spectroscopy. Moreover, their accurate calculated m/z values represent a closest fit consistent with the assigned structures.<smiles>NC(=O)c1cc(Br)cc(I)c1N</smiles>

(i)<smiles>[R][R]c1nc2c(I)cc(Br)cc2c(=O)[nH]1</smiles> 


\begin{tabular}{ccc}
\hline Compound & $\mathbf{R}$ & \% Yield of $\mathbf{4}$ \\
\hline $\mathbf{4 a}$ & $4-\mathrm{H}$ & 87 \\
$\mathbf{4 b}$ & $4-\mathrm{F}$ & 86 \\
$\mathbf{4 c}$ & $4-\mathrm{Cl}$ & 91 \\
$\mathbf{4 d}$ & $4-\mathrm{OMe}$ & 93 \\
\hline
\end{tabular}

Reagents and conditions: (i) 4- $\mathrm{RC}_{6} \mathrm{H}_{4} \mathrm{CHO}, \mathrm{I}_{2}$, ethanol, reflux, $7 \mathrm{~h}$

Scheme 2: Iodine-promoted cyclocondensation-dehydrogenation of $\mathbf{3}$ with aryldehydes

Quinazolin-4(3H)-one framework readily undergoes aromatization with reagents such as $\mathrm{SOCl}_{2}$, $\mathrm{POCl}_{3}$, and $\mathrm{PCl}_{5}$ in the presence or absence of an amine base to generate the 4-chloroquinazoline moiety. ${ }^{11,13,18}$ In this investigation, we subjected compounds 4a-d to phosphoryl chloridetriethylamine mixture under reflux for $7 \mathrm{~h}$ and isolated by aqueous work-up and recrystallization the corresponding novel 2-aryl-6-bromo-4-chloro-8-iodoquinazolines 5a-d (Scheme 3). These compounds are easily distinguished from the corresponding precursors by the absence of the amide signals in their NMR $\left({ }^{1} \mathrm{H}\right.$ and $\left.{ }^{13} \mathrm{C}\right)$ and IR spectra.<smiles>[R12]Cc1nc2c(I)cc(Br)cc2c(=O)[nH]1</smiles>

4a-d (i)<smiles>[R]CCCCc1nc(Cl)c2cc(Br)cc(I)c2n1</smiles>

5a-d

\begin{tabular}{ccc}
\hline Compound & $\mathbf{R}$ & \%Yield of 5 \\
\hline $\mathbf{5 a}$ & $4-\mathrm{H}$ & 77
\end{tabular}


$\mathbf{5 b}$

$5 c$

5d
$4-\mathrm{F}$

$4-\mathrm{Cl}$

$4-\mathrm{OMe}$
80

91

77

Reagents and conditions: (i) $\mathrm{POCl}_{3}, \mathrm{NEt}_{3}$, reflux, $6 \mathrm{~h}$

Scheme 3: Phosphoryl chloride promoted aromatization of $\mathbf{4 a - d .}$

With the halogenated quinazolines $\mathbf{5 a - d}$ in hand, we were ready to investigate their reactivity in palladium catalyzed cross-coupling reactions.

\subsection{Reactivity of compounds 5a-d in palladium catalyzed cross-coupling reactions}

2.2.1 Sonogashira cross-coupling of the 2-aryl-6-bromo-4-chloro-8-iodoquinazolines

Compounds 5a-d were subjected to the Sonogashira cross-coupling with phenylacetylene in the presence of $\mathrm{PdCl}_{2}\left(\mathrm{PPh}_{3}\right)_{2}-\mathrm{CuI}$ catalyst mixture and $\mathrm{Cs}_{2} \mathrm{CO}_{3}$ as a base in THF at r.t. for $18 \mathrm{~h}$ (Scheme 4). To our delight, we isolated in each case by column chromatography on silica gel a single monoalkynylated product characterized using a combination of NMR $\left({ }^{1} \mathrm{H}\right.$ and $\left.{ }^{13} \mathrm{C}\right)$ and IR spectroscopic techniques as well as mass spectrometry as the 8-alkynylated 2-aryl-6-bromo-4-chloroquinazolines 6a-h. In order to rationalize the observed selectivity, we explored the relative $\mathrm{Cs} p^{2}-\mathrm{X}$ bond dissociation energies of these mixed multihalogenated quinazolines by DFT method [B3LYP/6$311 \mathrm{G}(\mathrm{d})]$ using $2 \mathrm{a}$ as a model, which revealed the following trend: $\mathrm{I}(66.69 \mathrm{kcal} / \mathrm{mol})<\mathrm{Br}(78.17$ $\mathrm{Kcal} / \mathrm{mol})<\mathrm{Cl}(82.70 \mathrm{kcal} / \mathrm{mol})$. Based on DFT calculations and the observed experimental results, it is concluded that reactivity and selectivity of cross-coupling through C-8 relate to the $\mathrm{Cs} p^{2}-\mathrm{X}$ bond strength, which in this case favours substitution of the weakest $\mathrm{C} s p^{2}-\mathrm{I}_{\text {bond }}{ }^{11}$ in the presence of the highly activated $\mathrm{C}(4)-\mathrm{Cl}$ bond. ${ }^{18,19}$ 
<smiles>[R14]c1nc(Cl)c2cc(Br)cc(I)c2n1</smiles>

(i)<smiles>[R]C#Cc1cc(Br)cc2c(Cl)nc(CC[R])nc12</smiles>

$5 a-d$

6a-h

\begin{tabular}{cccc}
\hline Compound & $\mathbf{R}$ & $\mathbf{R}^{\prime}$ & \%Yield of 6 \\
\hline $\mathbf{6 a}$ & $4-\mathrm{H}$ & $-\mathrm{C}_{6} \mathrm{H}_{5}$ & 80 \\
$\mathbf{6 b}$ & $4-\mathrm{F}$ & $-\mathrm{C}_{6} \mathrm{H}_{5}$ & 85 \\
$\mathbf{6 c}$ & $4-\mathrm{Cl}$ & $-\mathrm{C}_{6} \mathrm{H}_{5}$ & 79 \\
$\mathbf{6 d}$ & $4-\mathrm{OMe}$ & $-\mathrm{C}_{6} \mathrm{H}_{5}$ & 68 \\
$\mathbf{6 e}$ & $4-\mathrm{H}$ & $-\mathrm{CH}_{2} \mathrm{CH}_{2} \mathrm{OH}$ & 78 \\
$\mathbf{6 f}$ & $4-\mathrm{F}$ & $-\mathrm{CH}_{2} \mathrm{CH}_{2} \mathrm{OH}$ & 65 \\
$\mathbf{6 g}$ & $4-\mathrm{Cl}$ & $-\mathrm{CH}_{2} \mathrm{CH}_{2} \mathrm{OH}$ & 87 \\
$\mathbf{6 h}$ & $4-\mathrm{OMe}$ & $-\mathrm{CH}_{2} \mathrm{CH}_{2} \mathrm{OH}$ & 73 \\
\hline
\end{tabular}

Reagents and conditions: (i) $\mathrm{R}^{\prime} \mathrm{C} \equiv \mathrm{CH}, \mathrm{PdCl}_{2}\left(\mathrm{PPh}_{3}\right)_{2}, \mathrm{CuI}, \mathrm{Cs}_{2} \mathrm{CO}_{3}$, THF, r.t., 18 h.

Scheme 4: Site-selective Pd-catalyzed Sonogashira cross-coupling of 5a-d

Next we focused our attention on the reactivity of the dihalogenated derivatives 6 in SuzukiMiyaura cross-coupling with arylboronic acids as models for $\mathrm{C} s p^{2}-\mathrm{C} s p^{2}$ bond formation.

\subsubsection{Suzuki-Miyaura cross-coupling of the 2-aryl-8-alkynyl-6-bromo-4-chloroquinzolines}

Attempted site-selective Suzuki-Miyaura cross-coupling of $6 \mathbf{a}$ with either 4-fluorophenylboronic acid or 4-methoxyphenylboronic acid (1.2 equiv.) in the presence of $\mathrm{PdCl}_{2}\left(\mathrm{PPh}_{3}\right)_{2}$ pre-catalyst as a 
source of active $\operatorname{Pd}(0)$ species and $\mathrm{K}_{2} \mathrm{CO}_{3}$ in dioxane (aq) under reflux led to complete replacement of the two halogen atoms after $2 \mathrm{~h}$. We then resorted to the use of the less reactive $\mathrm{Pd}\left(\mathrm{PPh}_{3}\right)_{4}$ as a source of active $\operatorname{Pd}(0)$ catalyst. We isolated after 3 h by column chromatography on silica gel two products in sequence in different ratio characterized using a combination of spectroscopic techniques as the 8-arylated 7a (major) and the symmetrical 6,8-diaryl substituted derivative 8a (minor), respectively (Scheme 5). These reaction conditions were extended to other substrates $\mathbf{6 b}-\mathbf{d}$ with arylboronic acids (1.2 equiv.) to afford the mono- $\mathbf{7 b}-\mathbf{h}$ (major) and diaryl-substituted derivatives $\mathbf{8 b}-\mathbf{g}$ (minor). Traces of the 4-benzaldehyde derivative $\mathbf{8 h}$ were detected by thin layer chromatography on silica gel in the reaction mixture, but could not be isolated by careful column chromatography. Despite the formation of two cross-coupled products, the reactivity of the $\mathrm{C}(4)-\mathrm{Cl}$ bond $(\mathrm{BDE}=82.70 \mathrm{kcal} / \mathrm{mol})$ under Suzuki-Miyaura conditions was found to be superior to that of the weaker $\mathrm{Cs} p^{2}-\mathrm{Br}$ bond $(\mathrm{BDE}=78.17 \mathrm{kcal} / \mathrm{mol})$. We rationalize the preponderance of the 4-aryl substituted quinazoline to be due to $\alpha$-nitrogen effect based on the literature precedents. ${ }^{18,19}$

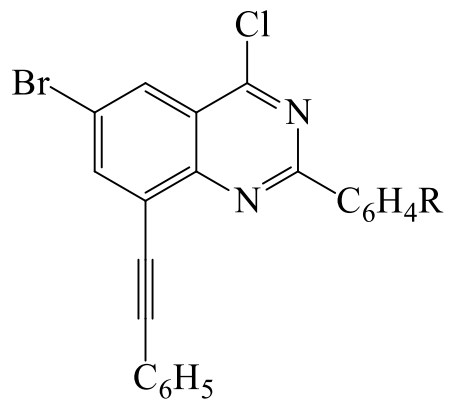

6a-d (i)<smiles>[R][R1]Cc1nc([Al])c2cc(Br)cc(C#Cc3ccccc3)c2n1</smiles>

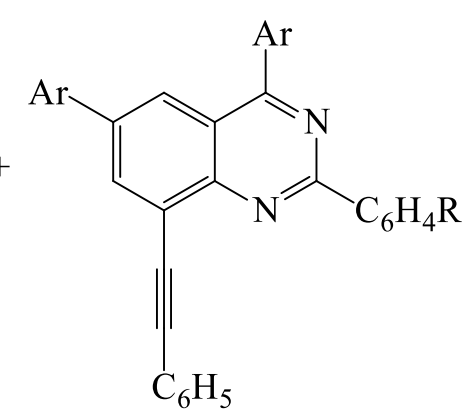

\begin{tabular}{ccccc}
\multicolumn{2}{c}{ 6a-d } & \multicolumn{3}{c}{ 7a-h } \\
\hline Compound & $\mathbf{R}$ & $\mathbf{A r}$ & \% Yield of 7 & \% Yield 8 \\
\hline $\mathbf{a}$ & $4-\mathrm{H}$ & $4-\mathrm{FC}_{6} \mathrm{H}_{4-}$ & 66 & 16 \\
b & $4-\mathrm{Cl}$ & $4-\mathrm{FC}_{6} \mathrm{H}_{4-}$ & 69 & 16 \\
$\mathbf{c}$ & $4-\mathrm{OMe}$ & $4-\mathrm{FC}_{6} \mathrm{H}_{4-}$ & 58 & 12
\end{tabular}




\begin{tabular}{ccccc} 
d & $4-\mathrm{H}$ & $4-\mathrm{MeOC}_{6} \mathrm{H}_{4}-$ & 71 & 10 \\
e & $4-\mathrm{F}$ & $4-\mathrm{MeOC}_{6} \mathrm{H}_{4} 4^{-}$ & 64 & 9 \\
$\mathbf{f}$ & $4-\mathrm{Cl}$ & $4-\mathrm{MeOC}_{6} \mathrm{H}_{4}-$ & 63 & 9 \\
g & $4-\mathrm{OMe}$ & $4-\mathrm{MeOC}_{6} \mathrm{H}_{4}^{-}$ & 60 & 7 \\
$\mathbf{h}$ & $4-\mathrm{F}$ & $4-\mathrm{H}(\mathrm{O}) \mathrm{CC}_{6} \mathrm{H}_{4-}$ & 51 & - \\
\hline
\end{tabular}

Reagents and conditions: (i) $\mathrm{ArB}(\mathrm{OH})_{2}, \mathrm{Pd}\left(\mathrm{PPh}_{3}\right)_{4}, \mathrm{~K}_{2} \mathrm{CO}_{3}$, dioxane (aq), $80^{\circ} \mathrm{C}, 2 \mathrm{~h}$

Scheme 5: Site selective Suzuki-Miyaura cross-coupling of 6a-d.

Encouraged by the successful differentiation in reactivity among the three halogen atoms within these series of substrates (trend: $\mathrm{C} s p^{2}-\mathrm{I}>\mathrm{C}(4)-\mathrm{Cl}>\mathrm{C} s p^{2}-\mathrm{Br}$ ), an investigation to effect one-pot Suzuki-Miyaura cross-coupling of the 8-alkynylated derivatives 6a-d with different arylboronic acids was pursued. We envisioned that the requisite mixed 4,6-diaryl-substituted quinazolines derived from the incipient $\mathbf{7}$ could be separated by conventional column chromatography from the preformed symmetrical 4,6-diaryl-substituted products 8. With this assumption in mind, we subjected compounds 6a-d to 1 equiv. of an arylboronic acid (4-fluorophenylboronic or 4methoxyphenylboronic acid) in aqueous dioxane in the presence of $\mathrm{Pd}\left(\mathrm{PPh}_{3}\right)_{4}$ catalyst source and $\mathrm{K}_{2} \mathrm{CO}_{3}$ as a base at $80{ }^{\circ} \mathrm{C}$ for $2 \mathrm{~h}$ (thin layer chromatography monitoring) followed by addition of the $2^{\text {nd }}$ arylboronic acid and further heating at this temperature for additional $3 \mathrm{~h}$ (Scheme 6). We isolated by column chromatography on silica gel the bis-Suzuki-Miyaura cross-coupled products 8a-h (minor) resulting from the $1^{\text {st }}$ step and the expected mixed 6,8-diaryl-substituted quinazoline derivatives $9 \mathbf{9}-\mathbf{h}$. The sequence of elution of $\mathbf{8}$ and $\mathbf{9}$ from the column was found to depend on the nature and polarity of the substituent on the para position of the 4- and 6-aryl rings. In general the 
4,6-bis(4-methoxyphenyl)-substituted derivatives eluted slower than derivatives bearing a combination of 4-fluorophenyl and 4-methoxyphenyl groups at either the 4- or 6-positions.

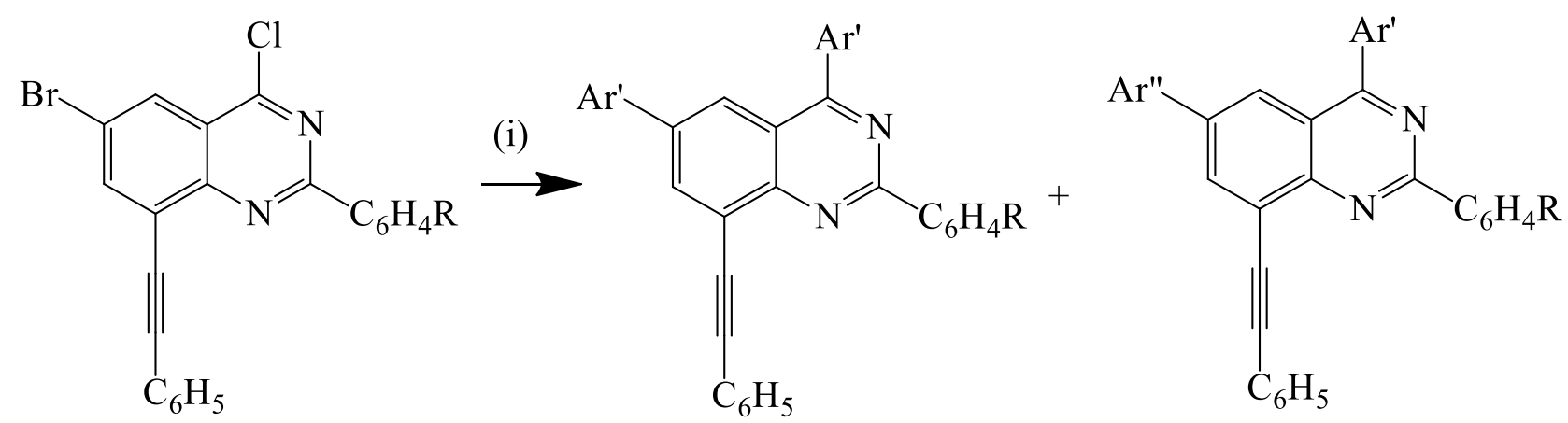

6a-d $\quad 8 a-h \quad 9 a-h$

\begin{tabular}{|c|c|c|c|c|c|}
\hline Compound & $\mathbf{R}$ & $\mathbf{A r} \mathbf{r}^{\prime}$ & Ar" & \% Yield of 8 & $\%$ Yield of 9 \\
\hline $\mathbf{a}$ & $4-\mathrm{H}$ & $4-\mathrm{MeOC}_{6} \mathrm{H}_{4^{-}}$ & $4-\mathrm{FC}_{6} \mathrm{H}_{4-}$ & 8 & 68 \\
\hline b & $4-\mathrm{F}$ & $4-\mathrm{MeOC}_{6} \mathrm{H}_{4^{-}}$ & 4- $\mathrm{FC}_{6} \mathrm{H}_{4-}$ & 9 & 60 \\
\hline c & $4-\mathrm{Cl}$ & $4-\mathrm{MeOC}_{6} \mathrm{H}_{4-}$ & $4-\mathrm{FC}_{6} \mathrm{H}_{4-}$ & 7 & 59 \\
\hline d & $4-\mathrm{OMe}$ & $4-\mathrm{MeOC}_{6} \mathrm{H}_{4-}$ & $4-\mathrm{FC}_{6} \mathrm{H}_{4-}$ & 7 & 54 \\
\hline $\mathbf{e}$ & $4-\mathrm{H}$ & $4-\mathrm{FC}_{6} \mathrm{H}_{4-}^{-}$ & 4- $\mathrm{MeOC}_{6} \mathrm{H}_{4^{-}}$ & 16 & 62 \\
\hline $\mathbf{f}$ & $4-\mathrm{Cl}$ & $4-\mathrm{FC}_{6} \mathrm{H}_{4-}$ & 4- $\mathrm{MeOC}_{6} \mathrm{H}_{4^{-}}$ & 14 & 65 \\
\hline $\mathbf{g}$ & 4-OMe & $4-\mathrm{FC}_{6} \mathrm{H}_{4-}$ & $4-\mathrm{MeOC}_{6} \mathrm{H}_{4-}$ & 12 & 54 \\
\hline $\mathbf{h}$ & $4-\mathrm{Cl}$ & $4-\mathrm{MeOC}_{6} \mathrm{H}_{4-}^{-}$ & $4-\mathrm{H}(\mathrm{O}) \mathrm{CC}_{6} \mathrm{H}_{4-}$ & 13 & 56 \\
\hline
\end{tabular}

Reagents and conditions: (i) $\mathrm{Ar}{ }^{\prime} \mathrm{B}(\mathrm{OH})_{2}$ (1 equiv.), $\mathrm{Pd}\left(\mathrm{PPh}_{3}\right)_{4}, \mathrm{~K}_{2} \mathrm{CO}_{3}$, dioxane (aq), $80^{\circ} \mathrm{C}, 2 \mathrm{~h}$; then $\mathrm{Ar}^{\prime \prime} \mathrm{B}(\mathrm{OH})_{2}\left(1.2\right.$ equiv.), $80^{\circ} \mathrm{C}, 3 \mathrm{~h}$.

Scheme 6: Sequential one-pot bis-Suzuki-Miyaura cross-coupling of $\mathbf{6 a - d}$ with arylboronic acids.

Although one-pot sequential metal-catalyzed cross-coupling reactions of multihalogenated aromatic and heteroaromatic compounds is a well-established procedure in the literature, to our 
knowledge, this strategy has only been applied recently on a single set of dihalogenated substrates in the quinazoline series. ${ }^{11}$ This prompted us to explore further the reactivity of $\mathbf{5 a}-\mathbf{d}$ in one-pot three-step Sonogashira cross-coupling reaction with different terminal acetylenes.

\subsubsection{One-pot Sonogashira cross-coupling of the 2-aryl-6-bromo-4-chloro-8-iodoquinzolines}

Since both $\mathrm{C}(4)-\mathrm{Cl}$ bond ${ }^{10}$ and $\mathrm{Cs} p^{2}$-I bond ${ }^{11}$ undergo Sonogashira cross-coupling at room temperature with ease (trend: $\mathrm{Cs} p^{2}-\mathrm{I}>\mathrm{C}(4)-\mathrm{Cl}$ ), we envisaged the possibility to effect one-pot three-step alkynylation of compounds $\mathbf{5 a - d}$ with different terminal acetylenes. We opted for the use of a single catalyst mixture and varied the reaction time and temperature as illustrated in Scheme 5. The first Sonogashira cross-coupling step was conducted under similar experimental conditions to those described in Scheme 1 using phenylacetylene as coupling partner followed after $18 \mathrm{~h}$ by addition of the second acetylene derivative (1.2 equiv.) and further stirring at this temperature for additional $18 \mathrm{~h}$ to displace the chlorine atom. Then a solution of the $3^{\text {rd }}$ terminal acetylene in THF was added and the mixture was heated at $60{ }^{\circ} \mathrm{C}$ for $2 \mathrm{~h}$. To our delight, we isolated by column chromatography on silica gel the corresponding novel unsymmetrical polycarbo-substituted quinazolines 10a-e, exclusively (Scheme 7). The observed selectivity of cross-coupling of $\mathbf{5 a - d}$ in conjunction with prior studies on the di- and trihalogenated quinazolines reveal the following general trend in reactivity of the $\mathrm{Cs} p^{2}$-halogen bonds for multi-halogenated quinazolines: $\mathrm{Cs} p^{2}$-I > $\mathrm{C}(4)-\mathrm{Cl}>\mathrm{Cs} p^{2}-\mathrm{Br}>\mathrm{C}(2)-\mathrm{Cl}>\mathrm{Cs} p^{2}-\mathrm{Cl}$. The 2-position of the pyrimidine ring is generally known to be less reactive to oxidative addition of Pd than the 4-position, but to be more reactive than the other chlorinated positions on the fused benzo ring. ${ }^{13}$ 


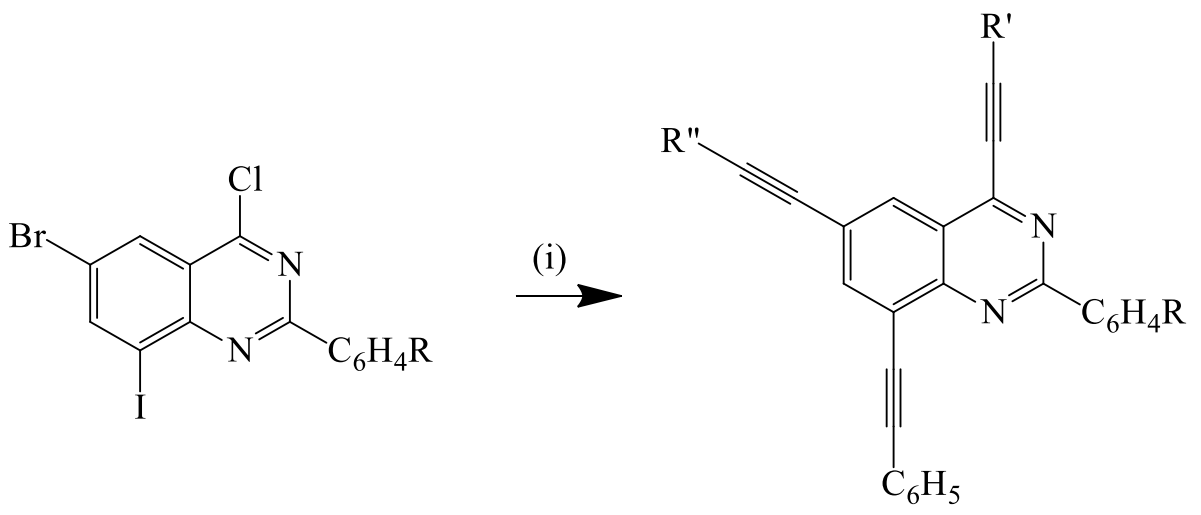

5a-d

$10 \mathbf{a}-\mathbf{e}$

\begin{tabular}{ccccc}
\hline Compound & $\mathbf{R}$ & $\mathbf{R}^{\prime}$ & $\mathbf{R}^{\prime \prime}$ & \% Yield of 10 \\
\hline $\mathbf{1 0 a}$ & $4-\mathrm{H}$ & $4-\mathrm{ClC}_{6} \mathrm{H}_{4}{ }^{-}$ & $-\left(\mathrm{CH}_{2}\right)_{2} \mathrm{OH}$ & 68 \\
$\mathbf{1 0 b}$ & $4-\mathrm{F}$ & $4-\mathrm{ClC}_{6} \mathrm{H}_{4}{ }^{-}$ & $-\left(\mathrm{CH}_{2}\right)_{2} \mathrm{OH}$ & 59 \\
$\mathbf{1 0 c}$ & $4-\mathrm{Cl}$ & $4-\mathrm{ClC}_{6} \mathrm{H}_{4}-$ & $-\left(\mathrm{CH}_{2}\right)_{2} \mathrm{OH}$ & 67 \\
$\mathbf{1 0 d}$ & $4-\mathrm{OMe}$ & $4-\mathrm{ClC}_{6} \mathrm{H}_{4}-$ & $-\left(\mathrm{CH}_{2}\right)_{2} \mathrm{OH}$ & 62 \\
$\mathbf{1 0 e}$ & $4-\mathrm{OMe}$ & $4-\mathrm{ClC}_{6} \mathrm{H}_{4^{-}}$ & 2-pyridyl- & 54 \\
\hline
\end{tabular}

Reagents and conditions: (i) $\mathrm{PhC} \equiv \mathrm{CH}$ (1 equiv.), $\mathrm{PdCl}_{2}\left(\mathrm{PPh}_{3}\right)_{2}, \mathrm{CuI}, \mathrm{Cs}_{2} \mathrm{CO}_{3}$, THF, r.t., 18 h; (ii) $\mathrm{R}^{\prime} \mathrm{C} \equiv \mathrm{CH}$ (1 equiv.), THF, r.t., $18 \mathrm{~h}$; (iii) $\mathrm{R}^{\prime \prime} \mathrm{C} \equiv \mathrm{CH}$ (1.2 equiv.), $\mathrm{THF}, 60^{\circ} \mathrm{C}, 3 \mathrm{~h}$.

Scheme 7: One-pot sequential three-step Sonogashira cross-coupling of 5a-d.

The molecular backbone of the polycarbo-substituted heterocycles $\mathbf{8}-\mathbf{1 0}$ comprises an electrondeficient quinazoline framework linked to the electron donating aryl rings directly or through $\pi$ conjugated spacer to comprise donor- $\pi$-acceptor systems with potential intramolecular charge transfer properties. As a prelude to compounds with potential photoelectronic properties, we evaluated the electronic absorption and emission properties of compounds $8 \mathbf{a}-\mathrm{g}, 9 \mathbf{a}-\mathbf{h}$ and $10 \mathbf{a}-\mathbf{e}$ in 
solution by means of UV-Vis and fluorescence spectrometry in conjunction with density functional theory (DFT) method.

\subsection{Photophysical property studies of compounds $8 \mathbf{8}-\mathbf{g}, 9 \mathbf{9}-\mathbf{h}$ and $\mathbf{1 0 a}-\mathbf{e}$}

\subsubsection{Electronic absorption and emission properties}

The UV-Vis spectra of compounds $8 \mathbf{a}-\mathbf{g}$ and $9 \mathbf{a}-\mathbf{h}$ in chloroform $\left(\mathrm{CHCl}_{3}\right)$ reveal the presence of two broad absorption bands of different intensity and wavelength in the ultraviolet region $\lambda$ 289$313 \mathrm{~nm}$ and $\lambda 378-395 \mathrm{~nm}$ attributed to the $\pi-\pi^{*}$ transition and the intramolecular donor-acceptor charge transfer absorption, respectively (Fig. 1a and 1b). Within each series, the intensity and wavelength of the absorption bands are influenced by the variation of substituents on the para position of the aryl groups. The red shift of the wavelength corresponding to the longest absorption band for compounds $\mathbf{8 g}$ and $\mathbf{9 g}$, for example, indicates that the presence of the strong electron donating 4-methoxyphenyl groups at positions 2 and 6 enhances the charge transfer character. The UV-Vis spectra of compounds $\mathbf{1 0 a}-\mathbf{e}$ in chloroform, on the other hand, reveal the presence of three absorption bands of different intensity (Fig. 1c). The first two bands in the ultraviolet region $\lambda 270$ 278 and $\lambda 303-332 \mathrm{~nm}$ are due to $\pi \rightarrow \pi^{*}$ transition of the conjugated quinazoline ring while the less intense broad bands in the visible region $\lambda 401-413 \mathrm{~nm}$ are due to the intramolecular donoracceptor charge transfer absorption. The bathochromic shift of the absorption bands observed for compounds $10 \mathbf{a}-\mathbf{e}$ as compared to $\mathbf{8 a}-\mathbf{g}$ and $9 \mathbf{a}-\mathbf{h}$ is due to extended $\pi$-conjugation of the donoracceptor systems. Both the absorption bands and the wavelength of these compounds are influenced by the variation of substituents on the heterocyclic framework. The fluorescence excitation spectra of compounds $8 \mathbf{a}-\mathbf{g}, 9 \mathbf{a}-\mathbf{h}$ and $10 \mathbf{a}-\mathbf{e}$ in chloroform at room temperature, on the other hand, are characterised by several bands located at the wavelength closest to those of their optimal absorption spectra. Their emission spectra in $\mathrm{CHCl}_{3}$ at the excitation wavelength, $\lambda \mathrm{ex}=320 \mathrm{~nm}$ (Fig. 1a-c), 
are characterised by single emission bands in the green region, $\lambda \mathrm{em}=450-475 \mathrm{~nm}$, due to $\pi \rightarrow \pi^{*}$ transition resulting from direct $\pi$-electron delocalization by the aryl groups and through the conjugate bridge towards the electron-deficient quinazoline ring. The intensity of the emission bands, Stokes shifts, and the fluorescence quantum yields of these compounds are influenced by the variation of aryl substituents on the heterocyclic scaffold (Table 1). Compounds $\mathbf{9 a}-\mathbf{h}$ bearing a combination of the moderately resonance-donating 4-fluorophenyl- and strongly donating 4methoxyphenyl substituents at the 4- and 6-positions exhibit similar pattern to that observed for compounds 8a-g. A 4-methoxyphenyl group at the 6-position enhances $\pi \rightarrow \pi^{*}$ transition more so than when at the 4-position of the heterocycle. The trend in emission intensity for compounds 10a-e reflects the resonance donating effect of the substituent on the 2-aryl ring $(\mathrm{H}<\mathrm{Cl}<\mathrm{F}<\mathrm{OMe})$ and the emission bands of the 2-(4-methoxyphenyl)-substituted derivatives 10d and 10e are slightly red shifted than the other three compounds (Fig. 1c). The $\pi, \pi^{*}$ state is much more polarizable than the ground state and a change in polarity of the solvent has been previously found to cause measurable displacements of the $\pi \rightarrow \pi^{*}$ transition for polycarbo-substituted quinazolines towards the red bands. ${ }^{10,11,20,21}$ Based on this literature precedent we decided to evaluate the emission behavior of compound $\mathbf{9 g}$ (solid lines) and 10e (broken lines) as representative models in solvents of different polarity (toluene and DMF) and their emission spectra are depicted in Figure 1d. 


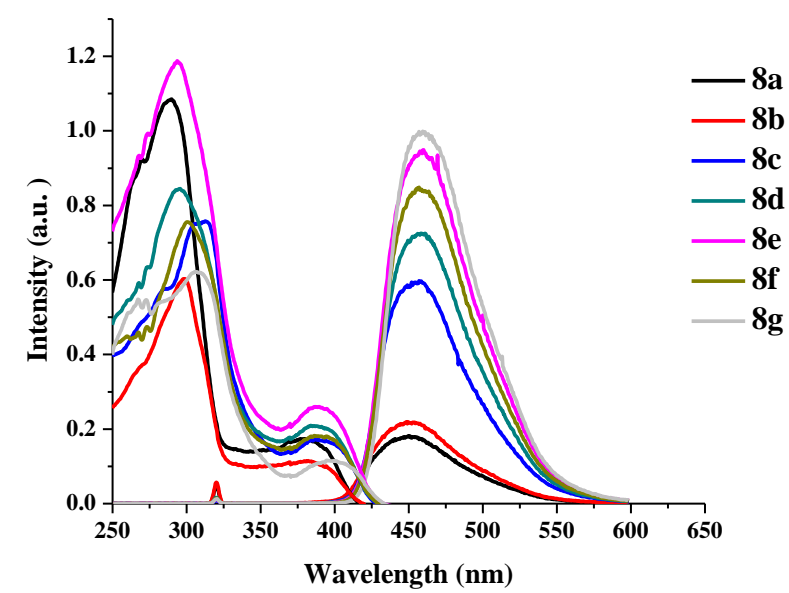

(a)

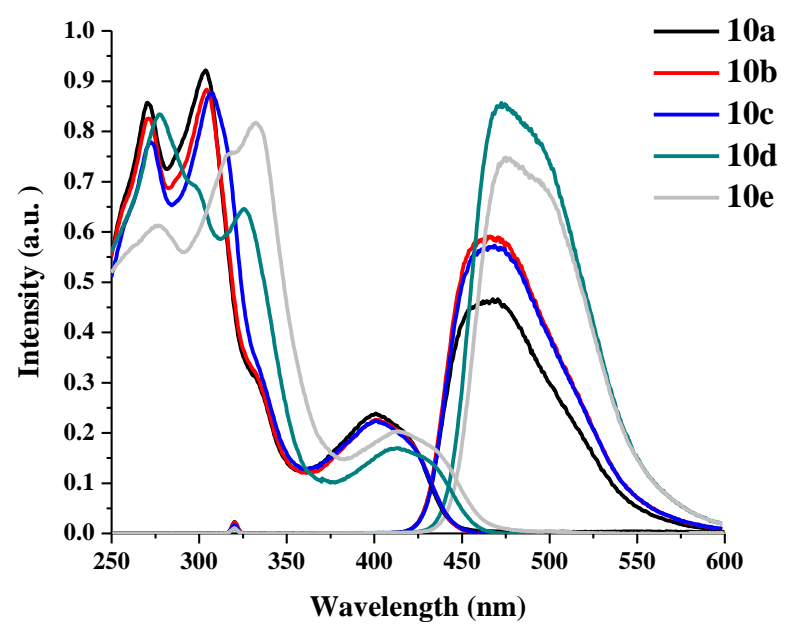

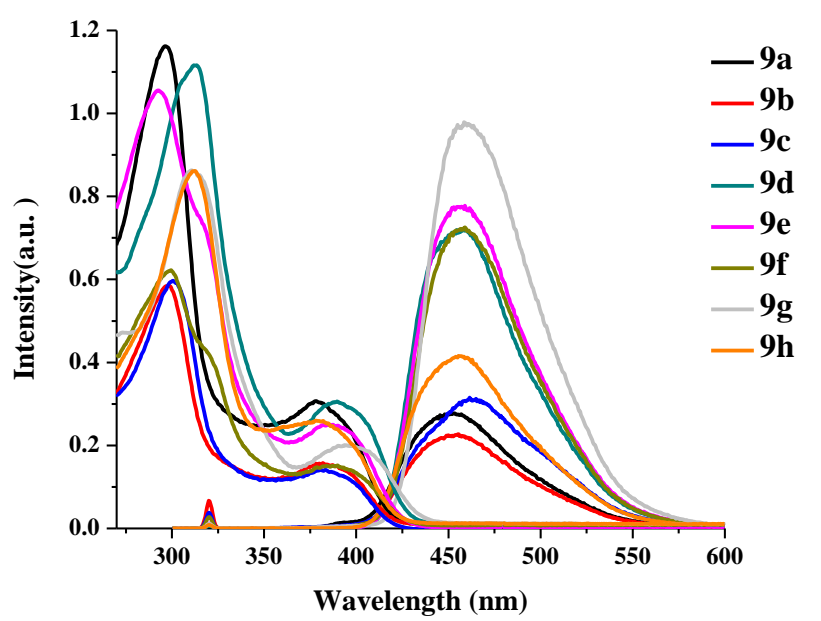

(b)

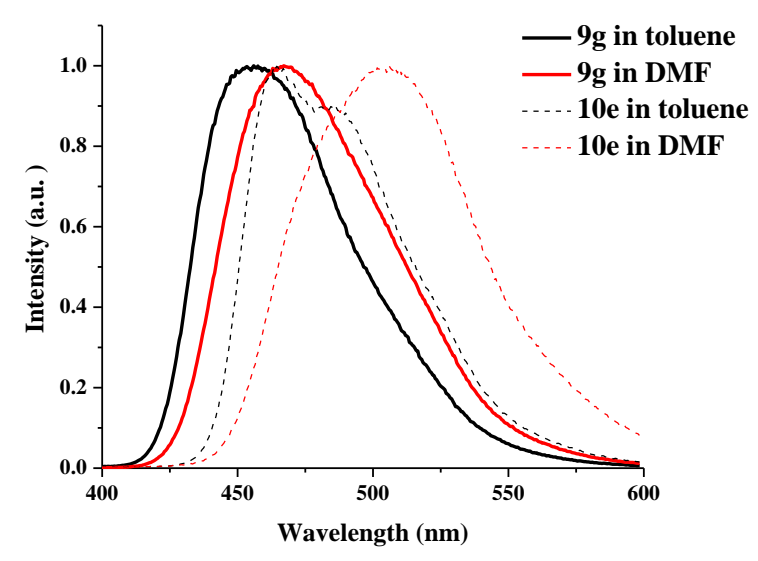

(d)

Figure 1: Absorption and normalized emission spectra of $\mathbf{8 a - g}(\mathrm{a}), \mathbf{9 a}-\mathbf{h}$ (b) and $\mathbf{1 0 a}-\mathbf{e}$ (c) in $\mathrm{CHCl}_{3}$ (r.t.) at $1.3 \times 10^{-5} \mathrm{~mol} / \mathrm{L}$ as well as normalized emission spectra of $\mathbf{9 g}$ and $\mathbf{1 0 e}$ in toluene and DMF (d) 
Table 1: The absorption and emission data for compounds $8 \mathbf{a}-\mathbf{g}, \mathbf{9 a}-\mathbf{h} \& \mathbf{1 0 a}-\mathbf{e}$.

\begin{tabular}{|c|c|c|c|c|}
\hline Compound & $\lambda_{\text {abs }}, \mathbf{n m}\left(\varepsilon \times 10^{3}, \mathrm{Mol}^{-1} \mathrm{~cm}^{-1}\right)$ & $\lambda_{\mathrm{em}}(\mathbf{n m})$ & $\begin{array}{c}{ }^{(a)} \text { Quantum } \\
\text { yields (Ф) }\end{array}$ & $\begin{array}{c}\text { Stokes } \\
\text { shifts }\end{array}$ \\
\hline $\mathbf{8 a}$ & $289(83.48) ; 382(13.32)$ & 450 & 0.038 & 3955 \\
\hline $8 \mathbf{b}$ & $298(46.41) ; 382(8.84)$ & 448 & 0.083 & 3856 \\
\hline $8 c$ & 312 (58.29); 387 (13.27) & 457 & 0.179 & 3957 \\
\hline 8d & 295 (65.01); $384(16.11)$ & 458 & 0.195 & 4207 \\
\hline $8 \mathbf{e}$ & 293 (91.39); 389 (20.02) & 457 & 0.181 & 3825 \\
\hline $8 f$ & $300(58.14) ; 388(13.93)$ & 456 & 0.255 & 3843 \\
\hline $8 g$ & $306(47.85) ; 395(8.94)$ & 460 & 0.365 & 3577 \\
\hline $9 a$ & $296(98.41) ; 378(23.62)$ & 453 & 0.054 & 4380 \\
\hline 9b & 298 (45.00); $382(12.10)$ & 455 & 0.089 & 4200 \\
\hline $9 c$ & 300 (45.92); $383(10.85)$ & 461 & 0.119 & 4417 \\
\hline 9d & $313(85.88) ; 389(23.55)$ & 459 & 0.146 & 3920 \\
\hline $9 e$ & 292 (81.20); 384 (19.23) & 459 & 0.167 & 4255 \\
\hline 9f & 299 (47.84); 384 (11.61) & 459 & 0.266 & 4255 \\
\hline $9 g$ & $310(66.36) ; 393(15.42)$ & 458 & 0.258 & 3611 \\
\hline $9 h$ & $312(66.25) ; 380(19.93)$ & 456 & 0.110 & 4386 \\
\hline 10a & 270 (65.93); 303 (70.87); 401 (18.35) & 467 & 0.115 & 3524 \\
\hline $10 \mathrm{~b}$ & 271 (63.51); 304 (67.93); 401 (17.36) & 465 & 0.152 & 3432 \\
\hline $10 \mathrm{c}$ & 272 (59.91); 307 (67.47); 401 (17.26) & 468 & 0.148 & 3570 \\
\hline 10d & 278 (64.16); 325 (49.68); 412 (13.06) & 472 & 0.233 & 3085 \\
\hline $10 \mathrm{e}$ & 275 (47.14); 332 (62.87); 413 (15.63) & 475 & 0.208 & 3160 \\
\hline
\end{tabular}

(a) The relative quantum yields in $\mathrm{CHCl}_{3}$ were calculated according to the equation indicated under Experimental section using quinine sulfate as the standard $\left(\Phi_{\mathrm{st}}=0.55\right)$ in $0.50 \mathrm{M} \mathrm{H}_{2} \mathrm{SO}_{4}$.

The fluorescence emission spectra of compounds $9 \mathrm{~g}$ and $10 \mathrm{e}$ are slightly red-shifted upon increasing the polarity of the solvent (toluene to DMF), which indicates an increase in dipole 
moment of excited state compared to ground state. The solvent polarity dependent electronic transitions may result from dipolar interaction with DMF thus suggesting the intramolecular charge transfer (ICT) of the emission state in which the HOMOs and LUMOs are presumably localized on the quinazoline-based moiety and the aryl rings. To further establish the structural features and molecular orbitals of compounds 8-10, we carried out a theoretical approach using DFT method at the B3LYP/6-31G* level to determine the HOMO and LUMO orbital energies of compounds 8a-g, 9a-h and $10 \mathbf{a}-\mathbf{e}$.

\subsubsection{Density functional theory data}

The geometries were optimized in the gas phase using CAM-B3LYP/6-31G(d,p $)^{22}$ as implemented in Gaussian 09 suite $^{23}$ to obtain reasonable structures for the subsequent electronic structure computations. The compounds were also fully optimized using the same functional and basis set in $\mathrm{CHCl}_{3}$ as the solvent based on the Polarizable Continuum Model (PCM) as developed by Tomasi et al. $^{24}$ The HOMO and LUMO surfaces of selected examples $(\mathbf{8 a}, \mathbf{9 a}$ and $\mathbf{1 0 e})$ in $\mathrm{CHCl}_{3}$ are illustrated Figure 2 (see Supplementary data for other compounds). In general there are no significant changes observed on the electron density distributions and the HOMO is delocalized over the entire molecule but with less contribution from the substituent at the 4-position whereas the LUMO shrinks toward the quinazoline core and these represent $\pi$ and $\pi^{*}$ orbitals, respectively. The calculated HOMO-LUMO gap for all the compounds at the B3LYP/6-31G(d,p) level is the range 5 to $6 \mathrm{eV}$. However, compounds $\mathbf{1 0}$ demonstrated the lowest band gaps 5.38 to $5.47 \mathrm{eV}$ due to increased conjugative effect by the $\pi$-spacer between the electron-deficient quinazoline framework and the surrounding substituents. Based on the orbital diagrams, the electronic transitions of all compounds can be attributed to ICT from the aryl substituents to the electron-deficient quinazoline framework. 


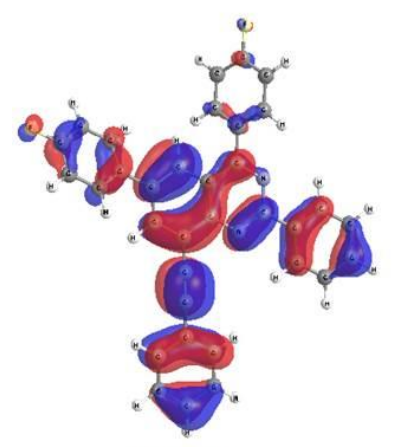

\section{HOMO}

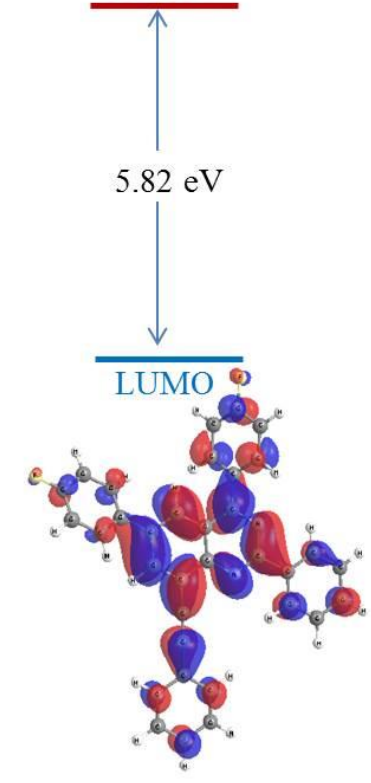

8a

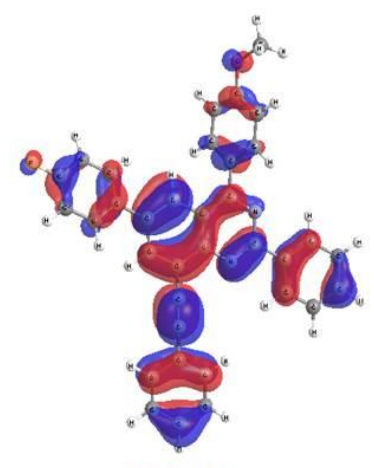

HOMO

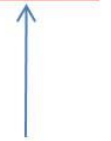

$$
5.83 \mathrm{eV}
$$
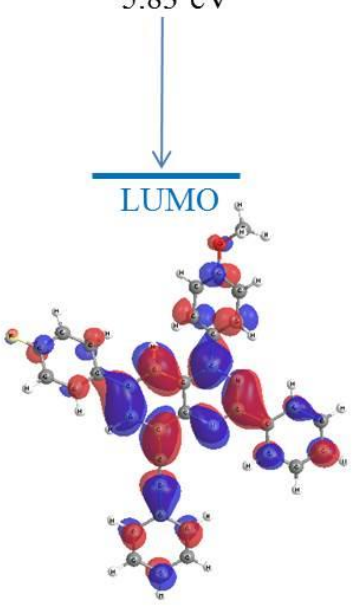

9a
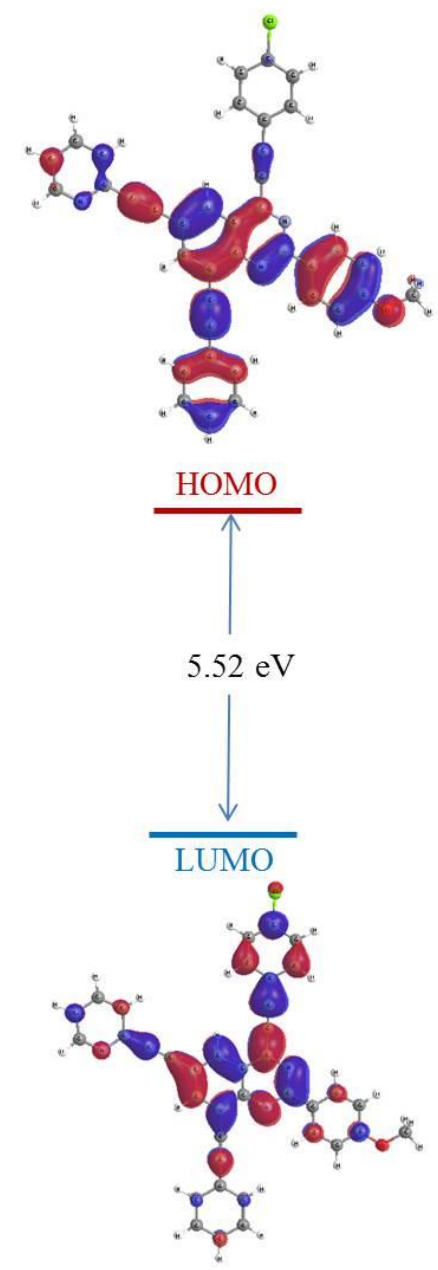

10e

Figure 2: Orbital topology of 8a, 9a and 10e in $\mathrm{CHCl}_{3}[\mathrm{CAM}-\mathrm{B} 3 \mathrm{LYP} / 6-31 \mathrm{G}(\mathrm{d}, \mathrm{p})$, isovalue $=0.02$ and density $=0.0004]$ as representative compounds

The UV-Vis spectra of compounds $8 \mathbf{8}-\mathbf{g}, 9 \mathbf{a}-\mathbf{h}$ and $\mathbf{1 0 a}-\mathbf{e}$ in chloroform were simulated and these are in agreement with those obtained experimentally (see Fig. 1). The simulated spectra of 8a-g are depicted in Figure 3 (see Supplementary Information for simulated spectra of compounds 9a-h and 10a-e). The UV spectrum of $8 \mathbf{a}$ was chosen as a representative model to assign the absorption bands in the electronic spectra. The lowest energy band at $346.8 \mathrm{~nm}$ has an oscillator strength of about 0.6 and the HOMO $\rightarrow$ LUMO transition (91.7\%) dominates the electron transition 
between the frontier orbitals for this band. The band at $277.5 \mathrm{~nm}$ with the highest oscillator strength of $c a 1.6$, on the other hand, is assigned to HOMO- $\rightarrow$ LUMO $(36.5 \%)$, HOMO- $1 \rightarrow$ LUMO+1 $(2.8 \%), \mathrm{HOMO} \rightarrow \mathrm{LUMO}+1(45.2 \%)$ and $\mathrm{HOMO} \rightarrow \mathrm{LUMO}+2(5.5 \%)$. The third band at $254.5 \mathrm{~nm}$ is mainly characterized with transitions of HOMO-6 $\rightarrow$ LUMO+1 (11.2\%), HOMO-2 $\rightarrow$ LUMO $(25.2 \%)$ and $\mathrm{HOMO} \rightarrow \mathrm{LUMO}+2(26.5 \%)$.

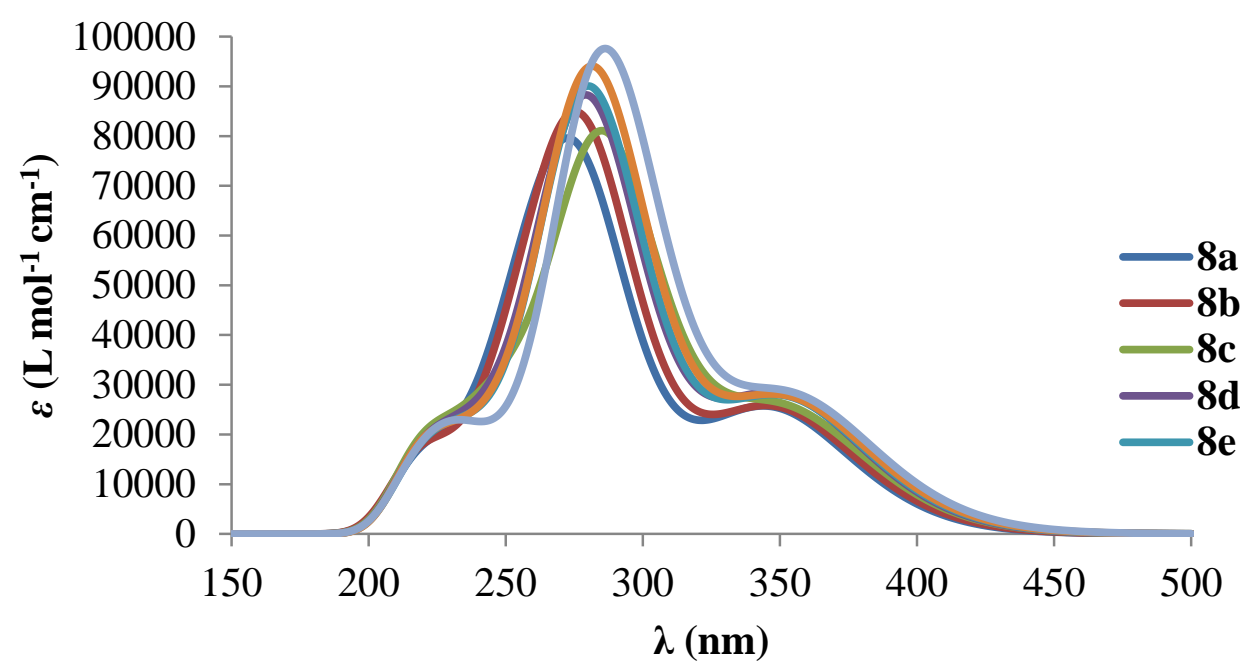

Figure 3(a): Simulated electronic spectra of compounds 8a-g

In conclusion, successful differentiation of the relative reactivity of the three $\mathrm{Cs} p^{2}$-halogen bonds $\left(\mathrm{C} s p^{2}-\mathrm{I}>\mathrm{C}(4)-\mathrm{Cl}>\mathrm{Cs} p^{2}-\mathrm{Br}\right)$ of the 2-aryl-4-chloro-6-bromo-8-iodoquinazolines facilitated sequential double cross-coupling (Sonogashira and subsequent single-pot double Suzuki-Miyaura) and single-pot three-step Sonogashira cross-coupling reactions to afford novel unsymmetrical polycarbo-substituted quinazolines. The observed results in conjunction with preceding literature data on the chloro-chloro and chloro-bromo substituted quinazolines reveal the following general trend in reactivity of the $\mathrm{C} s p^{2}$-halogen bonds for multi-halogenated quinazolines: $\mathrm{Cs} p^{2}-\mathrm{I}>\mathrm{C}(4)-\mathrm{Cl}$ $>\mathrm{C} s p^{2}-\mathrm{Br}>\mathrm{C}(2)-\mathrm{Cl}>\mathrm{C} s p^{2}-\mathrm{Cl}$. In contrast, the 4-chloroquinazoline framework has been found to be more preferred in cross-coupling reactions over the bromo- and iodo-substituted bonds. The 
example relates to the Sonogashira cross-coupling of 4-bromo- and 4-iodo-2trichloromethylquinazolines with cyclopropylacetylene and phenylacetylene, which afforded the corresponding 4-alkynyl-2-trichloromethylquinazolines in $15 \%$ and $9 \%$, respectively. ${ }^{25} \mathrm{We}$ conclude that selectivity in metal-mediated cross-coupling for multihalogenated quinazolines depends on both the intrinsic reactivity of the Csp ${ }^{2}$-halogen bond, which relates to its bond strength and the electronic position of the halogen atom on the electron deficient heterocycle. In our view, knowledge of the trend in reactivity of the $\mathrm{Cs} p^{2}-\mathrm{X}$ bonds for multihalogenated quinazolines will facilitate elaboration of the heterocyclic framework with various substituents to lead to novel polysubstituted quinazolines with interesting biological and/ or photophysical properties. Preliminary results on the photophysical property studies of compounds $\mathbf{8 a}-\mathbf{g}, \mathbf{9 a}-\mathbf{h}$ and $10 \mathbf{a}-\mathbf{e}$ reveal that intensity of the absorption and emission bands, Stokes shifts and the fluorescence quantum yields are influenced by the variation of substituents on the para position of the 2-, 4- and 6-aryl groups and the presence of the $\pi$-conjugated spacer. Due to its electron deficiency, the quinazoline moiety may provide a site for reduction in this donor- $\pi$-acceptor system, which makes the polycarbo-substituted quinazolines prepared in this investigation suitable candidates for further studies using cyclic voltammetry to probe oxidation and reduction potentials and the stability of the oxidized and reduced forms.

\section{Experimental}

Melting points were recorded on a Thermocouple digital melting point apparatus and are uncorrected. IR spectra were recorded as powders using a Bruker VERTEX 70 FT-IR Spectrometer with a diamond ATR (attenuated total reflectance) accessory by using the thin-film method. For 
column chromatography, Merck kieselgel $60(0.063-0.200 \mathrm{~mm})$ was used as stationary phase. NMR spectra were obtained as $\mathrm{CDCl}_{3}$ or DMSO- $d_{6}$ solutions using Varian Mercury $300 \mathrm{MHz}$ and Agilent $500 \mathrm{MHz}$ NMR spectrometers, and the chemical shifts are quoted relative to the TMS peak. Lowand high-resolution mass spectra were recorded at an ionization potential of $70 \mathrm{eV}$ using Micromass Autospec-TOF (double focusing high resolution) instrument. The UV-Vis spectra were recorded on a Cecil CE 9500 (9000 Series) UV-Vis spectrometer while emission spectra were taken using a Perkin Elmer LS45 fluorescence spectrometer. The quantum efficiencies of fluorescence ( $\Phi \mathrm{fl})$ were obtained with the following equation:

$$
\Phi_{\mathrm{x}}=\Phi_{\mathrm{st}} \times\left(F_{x} / F_{\text {st }}\right) \times\left(\mathrm{A}_{\mathrm{st}} / \mathrm{A}_{\mathrm{x}}\right) \times\left(n_{\mathrm{x}}{ }^{2} / n_{\mathrm{st}}{ }^{2}\right)
$$

$F$ denotes the area under the fluorescence band $(F=\operatorname{aIfl}(\lambda)$, where $\operatorname{Ifl}(\lambda)$ is the fluorescence intensity at each emission wavelength), A denotes the absorbance at the excitation wavelength, and $n$ is the refractive index of the solvent. ${ }^{26}$

Synthesis of 2-amino-5-bromo-3-iodobenzamide (3). A stirred solution of 2-aminobenzamide $(1.00 \mathrm{~g}, 7.34 \mathrm{mmol})$ in acetonitrile $(20 \mathrm{~mL})$ at room temperature was treated with $N$ bromosuccinimide $(1.36 \mathrm{~g}, 7.70 \mathrm{mmol})$. The mixture was stirred at room temperature for $0.5 \mathrm{~h}$ and then quenched with an ice-cold water. The resulting precipitate was filtered and the residue was recrystallized from acetonitrile to afford a pale yellow solid 2-amino-5-bromobenzamide (2) (1.47 g, 93\%), mp. $186-187^{\circ} \mathrm{C}\left(185-187^{\circ} \mathrm{C}^{27}\right)$. Compound 2 was dissolved in acetic acid $(20 \mathrm{~mL})$ followed by addition of $\mathrm{N}$-iodosuccimide at room temperature. The mixture was stirred at room temperature for $1 \mathrm{~h}$ and then quenched with an ice-cold aqueous sodium thiosulfate solution. The precipitate was filtered and recrystallized to afford $\mathbf{3}$ as a white solid (2.05 g, 88\%), mp. 238-240 ${ }^{\circ} \mathrm{C}$; $v_{\max }$ (ATR) 416, 540, 648, 804, 872, 1239, 1386, 1413, 1535, 1566, 1600, 1640, 3181, 3326, $3368 \mathrm{~cm}^{-1} ; \delta_{\mathrm{H}}\left(500 \mathrm{MHz}, \mathrm{CDCl}_{3}\right) 6.69(\mathrm{br} \mathrm{s}, 2 \mathrm{H}), 7.41(\mathrm{br} \mathrm{s}, 1 \mathrm{H}), 7.76(\mathrm{~d}, J=2.0 \mathrm{~Hz}, 1 \mathrm{H}), 7.85(\mathrm{~d}$, 
$J=2.0 \mathrm{~Hz}, 1 \mathrm{H}), 8.02($ br s, $1 \mathrm{H}) ; \delta_{\mathrm{C}}\left(125 \mathrm{MHz}, \mathrm{CDCl}_{3}\right) ; 87.6,106.3,116.5,131.7,143.2,148.7$, 169.7; $\mathrm{m} / \mathrm{z} 341\left(100, \mathrm{MH}^{+}\right)$; HRMS (ES): $\mathrm{MH}^{+}$, found $340.8786 . \mathrm{C}_{7} \mathrm{H}_{7}{ }^{79} \mathrm{BrIN}_{2} \mathrm{O}^{+}$requires 340.8786 . Typical procedure for the synthesis of the 2-aryl-6-bromo-8-iodoquinazolin-4(3H)-ones $4 a-d$.

6-Bromo-8-iodo-2-phenylquinazolin-4(3H)-one (4a). A stirred mixture of 2 (1.00 g, 2.94 mmol), benzaldehyde $(0.37 \mathrm{~g}, 3.52 \mathrm{mmol})$ and iodine $(1.49 \mathrm{~g}, 5.88 \mathrm{mmol})$ in ethanol $(100 \mathrm{~mL})$ was refluxed for $7 \mathrm{~h}$ and then allowed to cool to room temperature. The mixture was quenched with an ice-cold aqueous sodium thiosulfate solution and the precipitate was filtered and recrystallized to afford $4 \mathbf{a}$ as a white solid $(1.10 \mathrm{~g}, 87 \%), \mathrm{mp} .>345^{\circ} \mathrm{C}$; $v_{\max }$ (ATR) 527, 552, 636, 688, 698, 848, $946,1129,1291,1384,1446,1470,1563,1598,1658,3073,3164 \mathrm{~cm}^{-1} ; \delta_{\mathrm{H}}\left(500 \mathrm{MHz}\right.$, DMSO- $\left.d_{6}\right)$ 7.56-7.62 (m, 3H), $8.20(\mathrm{~d}, J=2.0 \mathrm{~Hz}, 1 \mathrm{H}), 8.25-8.29(\mathrm{~m}, 2 \mathrm{H}), 8.49(\mathrm{~d}, J=2.0 \mathrm{~Hz}, 1 \mathrm{H}), 12.86(\mathrm{~s}$, $1 \mathrm{H}) ; \delta_{\mathrm{C}}\left(125 \mathrm{MHz}, \mathrm{DMSO}-d_{6}\right) 103.5,119.7,122.9,128.5,128.9,129.2,132.4,132.7,145.9,148.1$, 153.7, 161.7; m/z $427\left(100, \mathrm{MH}^{+}\right)$; HRMS (ES): $\mathrm{MH}^{+}$, found 426.8937. $\mathrm{C}_{14} \mathrm{H}_{9}{ }^{79} \mathrm{BrIN}_{2} \mathrm{O}^{+}$requires 426.8943.

Typical procedure for the synthesis of the 2-aryl-6-bromo-4-chloro-8-iodoquinazolines 5a-d.

6-Bromo-4-chloro-8-iodo-2-phenylquinazoline (5a). A stirred mixture of $4(2.35 \mathrm{mmol})$ and phosphoryl chloride (6 equiv.) was treated dropwise with triethylamine (1.5 equiv.) at room temperature. The mixture was heated under reflux for $6 \mathrm{~h}$ and then allowed to cool to room temperature. An ice-cold water was added to the mixture and the aqueous layer was extracted with chloroform. The combined organic layers were washed with water and then dried over anhydrous $\mathrm{MgSO}_{4}$, filtered and evaporated under reduced pressure to afford $\mathbf{5 a}$ as a white solid ( $\left.0.80 \mathrm{~g}, 77 \%\right)$, mp. $194-195{ }^{\circ} \mathrm{C} ; v_{\max }$ (ATR) 534, 685, 704, 863, 1022, 1212, 1297, 1330, 1455, 1551, $1582 \mathrm{~cm}^{-1}$; $\delta_{\mathrm{H}}\left(500 \mathrm{MHz}, \mathrm{CDCl}_{3}\right) 7.51-7.53(\mathrm{~m}, 3 \mathrm{H}), 8.31(\mathrm{~d}, J=2.0 \mathrm{~Hz}, 1 \mathrm{H}), 8.49(\mathrm{~d}, J=2.0 \mathrm{~Hz}, 1 \mathrm{H}), 8.59$ $(\mathrm{dd}, J=2.0$ and $8.0 \mathrm{~Hz}, 2 \mathrm{H}) ; \delta_{\mathrm{C}}\left(125 \mathrm{MHz}, \mathrm{CDCl}_{3}\right) 103.5,122.1,123.1,128.4,128.7,129.0,131.8$, 
135.6, 147.3, 149.8, 160.7, 161.6; m/z 445 (100, $\left.\mathrm{MH}^{+}\right)$; HRMS (ES): $\mathrm{MH}^{+}$, found 444.8602. $\mathrm{C}_{14} \mathrm{H}_{8}{ }^{79} \mathrm{Br}^{35} \mathrm{ClIN}_{2}{ }^{+}$requires 444,8604 .

Typical procedure for the site-selective Sonogashira cross-coupling of $6 a-d$.

6-Bromo-4-chloro-2-phenyl-8-(phenylethynyl)quinazoline (6a). A stirred mixture of 5a (0.30 $\mathrm{g}, 0.67 \mathrm{mmol}), \mathrm{PdCl}_{2}\left(\mathrm{PPh}_{3}\right)_{2}(0.047 \mathrm{~g}, 0.06 \mathrm{mmol}), \mathrm{CuI}(0.006 \mathrm{~g}, 0.03 \mathrm{mmol})$ and $\mathrm{Cs}_{2} \mathrm{CO}_{3}(0.32 \mathrm{~g}$, $1.00 \mathrm{mmol})$ in THF $(10 \mathrm{~mL})$ was purged with argon gas for 30 minutes. Phenyl acetylene $(0.075 \mathrm{~g}$, $0.74 \mathrm{mmol}$ ) was added to the mixture using a syringe. The reaction mixture was stirred at room temperature for 24 hours and then quenched with ice-cold water. The product was extracted into chloroform and the combined organic layers were washed with water, dried over $\mathrm{Na}_{2} \mathrm{SO}_{4}$, filtered and evaporated under reduced pressure. The residue was purified by column chromatography on silica gel to afford $6 \mathbf{a}$ as a yellow solid $(0.21 \mathrm{~g}, 80 \%), \mathrm{R}_{\mathrm{f}}(2: 1$ hexane/toluene $)$ 0.57, mp. 166-168 ${ }^{\circ} \mathrm{C} ; v_{\max }$ (ATR) 503, 528, 561, 613, 681, 708, 751, 839, 860, 1332, 1413, 1458, 1551, 2213, 3058 $\mathrm{cm}^{-1} ; \delta_{\mathrm{H}}\left(500 \mathrm{MHz}, \mathrm{CDCl}_{3}\right) 7.43-7.46(\mathrm{~m}, 3 \mathrm{H}), 7.53-7.55(\mathrm{~m}, 3 \mathrm{H}), 7.69-7.72(\mathrm{~m}, 2 \mathrm{H}), 8.18(\mathrm{~d}, J=$ $2.0 \mathrm{~Hz}, 1 \mathrm{H}), 8.33(\mathrm{~d}, J=2.0 \mathrm{~Hz}, 1 \mathrm{H}), 8.65-8.67(\mathrm{~m}, 2 \mathrm{H}) ; \delta_{\mathrm{C}}\left(125 \mathrm{MHz}, \mathrm{CDCl}_{3}\right)$ 84.5, 98.4, 121.1, $122.7,123.4,125.5,127.8,128.5,128.7,129.0,129.1,131.6,132.0,136.2,140.9,150.7,160.3$, $161.6 \mathrm{~m} / \mathrm{z} 419\left(100, \mathrm{MH}^{+}\right)$; HRMS (ES): $\mathrm{MH}^{+}$, found 418.9944. $\mathrm{C}_{22} \mathrm{H}_{13}{ }^{79} \mathrm{Br}^{35} \mathrm{ClN}_{2}{ }^{+}$requires 418.9951.

\section{Typical procedure for the Suzuki cross-coupling of $6 a-d$.}

6-Bromo-4-(4-fluorophenyl)-2-phenyl-8-(phenylethynyl)quinazoline (7a) and 4,6-bis(4fluorophenyl)-2-phenyl-8-(phenylethynyl)quinazoline (8a). A stirred mixture of $6 \mathbf{a}(0.20 \mathrm{~g}, 0.48$ $\mathrm{mmol}), \mathrm{Pd}\left(\mathrm{PPh}_{3}\right)_{4}(0.027 \mathrm{~g}, 0.024 \mathrm{mmol})$ and $\mathrm{K}_{2} \mathrm{CO}_{3}(0.099 \mathrm{~g}, 0.72 \mathrm{mmol})$ in 3:1 dioxane-water (v/v, $10 \mathrm{~mL})$ was purged with argon gas for 30 minutes. 4-Fluorophenylboronic acid (0.067 g, 0.48 mmol) was added to the mixture using a syringe. The reaction mixture was heated at $100{ }^{\circ} \mathrm{C}$ for $2 \mathrm{~h}$ 
and then quenched with an ice-cold water. The product was extracted into chloroform and the combined organic layers were washed with water, dried over $\mathrm{Na}_{2} \mathrm{SO}_{4}$, filtered and evaporated under reduced pressure. The residue was purified by column chromatography on silica gel to afford $7 \mathbf{a}$ and $\mathbf{8 a}$ in sequence.

7a: Yellow solid (0.15 g, 66\%), $\mathrm{R}_{\mathrm{f}}\left(2: 1\right.$ hexane/toluene) $0.34, \mathrm{mp} .191-193{ }^{\circ} \mathrm{C} ; v_{\max }$ (ATR) 524 , $562,689,755,847,1158,1225,1252,1372,1418,1509,1536,1601,2213,2922,3069 \mathrm{~cm}^{-1} ; \delta_{\mathrm{H}}$ $\left(500 \mathrm{MHz}, \mathrm{CDCl}_{3}\right) 7.33(\mathrm{t}, J=9.0 \mathrm{~Hz}, 2 \mathrm{H}), 7.44-7.48(\mathrm{~m}, 3 \mathrm{H}), 7.53-7.57(\mathrm{~m}, 3 \mathrm{H}), 7.74-7.76(\mathrm{~m}$, 2H), $7.88(\mathrm{t}, J=9.0 \mathrm{~Hz}, 2 \mathrm{H}), 8.17(\mathrm{~d}, J=2.0 \mathrm{~Hz}, 1 \mathrm{H}), 8.19(\mathrm{~d}, J=2.0 \mathrm{~Hz}, 1 \mathrm{H}), 8.77-8.80(\mathrm{~m} 2 \mathrm{H})$; $\delta_{\mathrm{C}}\left(125 \mathrm{MHz}, \mathrm{CDCl}_{3}\right) 85.1,97.9,116.0\left(\mathrm{~d},{ }^{2} J_{\mathrm{CF}}=21.9 \mathrm{~Hz}\right), 119.9,122.5,123.0,125.7,128.5$, 128.6, 128.8, 128.9, 130.0, 131.1, 132.0, $132.2\left(\mathrm{~d},{ }^{3} J_{\mathrm{CF}}=8.6 \mathrm{~Hz}\right), 133.1\left(\mathrm{~d},{ }^{4} J_{\mathrm{CF}}=2,9 \mathrm{~Hz}\right), 137.6$, 139.9, 151.0, 160.4, $164.2\left(\mathrm{~d},{ }^{1} J_{\mathrm{CF}}=250.3 \mathrm{~Hz}\right), 166.7 ; \mathrm{m} / \mathrm{z} 479\left(100, \mathrm{MH}^{+}\right)$; HRMS (ES): $\mathrm{MH}^{+}$, found 479.0557. $\mathrm{C}_{28} \mathrm{H}_{17}{ }^{79} \mathrm{BrFN}_{2}{ }^{+}$requires 479.0559 .

8a: Yellow solid (0.04 g, 16\%), $\mathrm{R}_{\mathrm{f}}\left(2: 1\right.$ hexane/toluene) $0.32, \mathrm{mp} .196-198^{\circ} \mathrm{C} ; v_{\max }$ (ATR) 518 , $556,567,693,716,754,783,802,834,848,1157,1226,1491,1510,1602,2927,3059 \mathrm{~cm}^{-1} ; \delta_{\mathrm{H}}$ $\left(500 \mathrm{MHz}, \mathrm{CDCl}_{3}\right) 7.17(\mathrm{t}, J=8.5 \mathrm{~Hz}, 2 \mathrm{H}), 7.31(\mathrm{t}, J=8.5 \mathrm{~Hz}, 2 \mathrm{H}), 7.43-7.45(\mathrm{~m}, 3 \mathrm{H}), 7.51-7.54$ (m, 3H), $7.60(\mathrm{dd}, J=5.0$ and $8.0 \mathrm{~Hz}, 2 \mathrm{H}), 7.75(\mathrm{dd}, J=2.0$ and $8.0 \mathrm{~Hz}, 2 \mathrm{H}), 7.93(\mathrm{dd}, J=5.5$ and $8.0 \mathrm{~Hz}, 2 \mathrm{H}), 8.13(\mathrm{~d}, J=2.0 \mathrm{~Hz}, 1 \mathrm{H}), 8.31(\mathrm{~d}, J=2.0 \mathrm{~Hz}, 1 \mathrm{H}), 8.80(\mathrm{~m}, 2 \mathrm{H}) ; \delta_{\mathrm{C}}\left(125 \mathrm{MHz}, \mathrm{CDCl}_{3}\right)$ 86.3, 96.6, $115.9\left(\mathrm{~d},{ }^{2} J_{\mathrm{CF}}=21.6 \mathrm{~Hz}\right), 116.1\left(\mathrm{~d},{ }^{2} J_{\mathrm{CF}}=21.7 \mathrm{~Hz}\right), 21.8,123.3,124.1,128.5,128.6$, $128.7,128.8,128.9\left(\mathrm{~d},{ }^{3} J_{\mathrm{CF}}=8.2 \mathrm{~Hz}\right), 129.0,130.9,131.9,132.2\left(\mathrm{~d},{ }^{3} J_{\mathrm{CF}}=8.5 \mathrm{~Hz}\right), 133.6\left(\mathrm{~d},{ }^{4} J_{\mathrm{CF}}=\right.$ $3.1 \mathrm{~Hz}), 135.4\left(\mathrm{~d},{ }^{4} J_{\mathrm{CF}}=3.1 \mathrm{~Hz}\right), 136.5,137.8,138.4,151.3,160.1,162.9\left(\mathrm{~d},{ }^{1} J_{\mathrm{CF}}=247.1 \mathrm{~Hz}\right)$, $164.0\left(\mathrm{~d},{ }^{1} J_{\mathrm{CF}}=249.4 \mathrm{~Hz}\right), 167.6 ; \mathrm{m} / \mathrm{z} 495\left(100, \mathrm{MH}^{+}\right)$; HRMS (ES): $\mathrm{MH}^{+}$, found 495.1685. $\mathrm{C}_{34} \mathrm{H}_{21} \mathrm{~F}_{2} \mathrm{~N}_{2}{ }^{+}$requires 495.1673 .

Typical procedure for the one-pot sequential Suzuki-Miyaura cross-coupling of $6 a-d$. 

fluorophenyl)-4-(4-methoxyphenyl)-2-phenyl-8-(phenylethynyl)quinazoline (9a). A stirred mixture of $6 \mathbf{a}(0.30 \mathrm{~g}, 0.72 \mathrm{mmol}), \mathrm{Pd}\left(\mathrm{PPh}_{3}\right)_{4}(0.041 \mathrm{~g}, 0.036 \mathrm{mmol})$ and $\mathrm{K}_{2} \mathrm{CO}_{3}(0.30 \mathrm{~g}, 2.16$ mmol) in 3:1 dioxane-water (v/v, $15 \mathrm{~mL})$ was purged with argon gas for 30 minutes. 4Methoxyphenylboronic acid $(0.11 \mathrm{~g}, 0.72 \mathrm{mmol})$ was added to the mixture using a syringe. The reaction mixture was heated at $100{ }^{\circ} \mathrm{C}$ for $2 \mathrm{~h}$ and then a solution of (4-fluorophenyl)boronic acid $(0.12 \mathrm{~g}, 0.86 \mathrm{mmol})$ in dioxane $(5 \mathrm{~mL})$ was added via a syringe and heating was continued for additional $4 \mathrm{~h}$. The mixture was allowed to cool to room temperature and the quenched with an icecold water. The product was extracted into chloroform and the combined organic layers were washed with water, dried over $\mathrm{Na}_{2} \mathrm{SO}_{4}$, filtered and evaporated under reduced pressure. The residue was purified by column chromatography on silica gel to afford $\mathbf{8 d}(0.03 \mathrm{~g}, 08 \%), \mathrm{R}_{\mathrm{f}}$ (toluene) 0.25 , mp. $223-224^{\circ} \mathrm{C}$ and

9a as yellow solid $(0.25 \mathrm{~g}, 68 \%), \mathrm{R}_{\mathrm{f}}\left(1: 1\right.$ hexane/toluene) $054, \mathrm{mp} .220-222{ }^{\circ} \mathrm{C}$; $v_{\max }$ (ATR) $512,557,691,758,782,818,833,1174,1223,1253,1396,1461,1534,1601,2912,3052 \mathrm{~cm}^{-1} ; \delta_{\mathrm{H}}$ $\left(500 \mathrm{MHz}, \mathrm{CDCl}_{3}\right) 3.94(\mathrm{~s}, 3 \mathrm{H}), 7.14(\mathrm{~d}, J=8.5 \mathrm{~Hz}, 2 \mathrm{H}), 7.18(\mathrm{t}, J=8.5 \mathrm{~Hz}, 2 \mathrm{H}), 7.43-7.45(\mathrm{~m}$, 3H), 7.53-7.55 (m, 3H), $7.63(\mathrm{dd}, J=5.0$ and $8.5 \mathrm{~Hz}, 2 \mathrm{H}), 7.77(\mathrm{dd}, J=1.5$ and $8.0 \mathrm{~Hz}, 2 \mathrm{H}), 7.93$ $(\mathrm{d}, J=9.0 \mathrm{~Hz}, 2 \mathrm{H}), 8.24(\mathrm{~d}, J=3.0 \mathrm{~Hz}, 1 \mathrm{H}), 8.32(\mathrm{~d}, J=2.5 \mathrm{~Hz}, 1 \mathrm{H}), 8.83(\mathrm{~d}, J=8.5 \mathrm{~Hz}, 2 \mathrm{H}) ; \delta_{\mathrm{C}}$ $\left(125 \mathrm{MHz} \mathrm{CDCl}_{3}\right) 55.5,86.5,96.3,114.1,116.0\left(\mathrm{~d},{ }^{2} J_{\mathrm{CF}}=20.8 \mathrm{~Hz}\right), 121.9,123.4,123.9,124.6$, $128.2,128.4,128.5,128.6,128.8,128.9,\left(\mathrm{~d},{ }^{3} J_{\mathrm{CF}}=8.5 \mathrm{~Hz}\right), 129.0,130.7,131.9,135.6\left(\mathrm{~d},{ }^{4} J_{\mathrm{CF}}=2.8\right.$ $\mathrm{Hz}), 136.2,138.0,138.1,151.4,160.1,161.4,162.8\left(\mathrm{~d},{ }^{1} J_{\mathrm{CF}}=246.5 \mathrm{~Hz}\right), 168.2 ; \mathrm{m} / \mathrm{z} 507(100$, $\mathrm{MH}^{+}$); HRMS (ES): $\mathrm{MH}^{+}$, found 507.1864. $\mathrm{C}_{35} \mathrm{H}_{24} \mathrm{FN}_{2} \mathrm{O}^{+}$requires 507.1873.

\section{Typical procedure for the one-pot three-step Sonogashira cross-coupling of $5 a-d$.}




\section{4-(4-(4-Chlorophenylethynyl)-2-phenyl-8-(phenylethynyl)quinazolin-6-yl)but-3-yn-1-ol}

(10a). A stirred mixture of $\mathbf{5 a}(0.30 \mathrm{~g}, 0.67 \mathrm{mmol}), \mathrm{PdCl}_{2}\left(\mathrm{PPh}_{3}\right)_{2}(0.077 \mathrm{~g}, 0.067 \mathrm{mmol}), \mathrm{CuI}(0.006$ $\mathrm{g} ; 0.033 \mathrm{mmol})$ and $\mathrm{Cs}_{2} \mathrm{CO}_{3}(0.87 \mathrm{~g}, 2.68 \mathrm{mmol})$ in $\mathrm{THF}(15 \mathrm{~mL})$ was purged with argon gas for 30 minutes. Phenyl acetylene $(0.068 \mathrm{~g}, 0.67 \mathrm{mmol})$ was added to the mixture using a syringe. The reaction mixture was stirred at room temperature for $18 \mathrm{~h}$ and then a solution of 4-chlorophenyl acetylene $(0.091 \mathrm{~g}, 0.67 \mathrm{mmol})$ in THF $(5 \mathrm{~mL})$ was added via a syringe. The mixture was stirred at room temperature for additional $18 \mathrm{~h}$ and a solution of 3-butyn-1-ol (0.056 g, $0.80 \mathrm{mmol})$ in THF (5 $\mathrm{mL}$ ) was added via a syringe under nitrogen atmosphere. The mixture was heated under reflux for 3 $\mathrm{h}$ and then allowed to cool to room temperature. An ice-cold water was added to the mixture and the product was extracted into chloroform. The combined organic layers were washed with water, dried over $\mathrm{Na}_{2} \mathrm{SO}_{4}$, filtered and evaporated under reduced pressure. The residue was purified by column chromatography on silica gel to afford a yellow solid 10a as a yellow solid $(0.23 \mathrm{~g}, 68 \%), \mathrm{R}_{\mathrm{f}}(2: 1$ hexane-ethyl acetate) 0.48 , mp. $188-189{ }^{\circ} \mathrm{C} ; v_{\max }$ (ATR) 524, 613, 683, 715, 752, 828, 1013, 1043, $1090,1404,1490,1538,2208,2923,3049,3287 \mathrm{~cm}^{-1} ; \delta_{\mathrm{H}}\left(500 \mathrm{MHz}, \mathrm{CDCl}_{3}\right) 1.85(\mathrm{t}, J=6.0 \mathrm{~Hz}$, 1H), $2.78(\mathrm{t}, J=6.0 \mathrm{~Hz}, 2 \mathrm{H}), 3.89(\mathrm{q}, J=6.0 \mathrm{~Hz}, 2 \mathrm{H}), 7.42-7.45(\mathrm{~m}, 6 \mathrm{H}), 7.53-7.55(\mathrm{~m}, 3 \mathrm{H}), 7.70-$ $7.73(\mathrm{~m}, 3 \mathrm{H}), 8.11(\mathrm{~d}, J=2.0 \mathrm{~Hz}, 1 \mathrm{H}), 8.29(\mathrm{~d}, J=2.0 \mathrm{~Hz}, 1 \mathrm{H}), 8.72-8.76(\mathrm{~m}, 2 \mathrm{H}) ; \delta_{\mathrm{C}}(125 \mathrm{MHz}$, $\left.\mathrm{CDCl}_{3}\right)$ 24.2, 61.3, 81.4, 85.5, 86.5, 90.1, 97.3, 97.5, 119.8, 122.8, 123.3, 123.9, 124.0, 128.7, $128.9,129.1,129.2,129.4,130.2,131.4,132.2,134.1,136.8,137.5,140.7,150.6,152.5,161.4 ; \mathrm{m} / \mathrm{z}$ $509\left(100, \mathrm{MH}^{+}\right)$; HRMS (ES): $\mathrm{MH}^{+}$, found 509.1426. $\mathrm{C}_{34} \mathrm{H}_{22}{ }^{35} \mathrm{ClN}_{2} \mathrm{O}^{+}$requires 509.1421.

\section{Supplementary Materials}


Experimental procedures for the synthesis of all the new compounds (S1) and the frontier molecular orbitals of compounds $8 \mathbf{a}-\mathbf{h}, 9 \mathbf{a}-\mathbf{h}$ and $10 \mathbf{a}-\mathbf{e}(\mathbf{S 2})$ as well as calculated results for the absorption of compounds $\mathbf{8 a}(\mathbf{S 3})$ are listed in the supplementary materials.

\section{Acknowledgements}

The authors are grateful to the University of South Africa and the National Research Foundation in South Africa for financial assistance. The computational work used the Extreme Science and Engineering Discovery Environment (XSEDE), which is supported by National Science Foundation grant number OCI-1053575. LR and PR acknowledge the facilities from the University of Mauritius.

\section{References}

1. Kitano, Y.; Suzuki, T.; Kawahara, E.; Yamazaki, T. Bioorg. Med. Chem. Lett. 2007, 17, $5863-5867$.

2. Bernotas, R.C.; Ullrich, J.W.; Travins, J.M.; Wrobel, J.E.; Unwalla, R.J. WO2009020683 A2, 12 February 2009.

3. Sardon, T.; Cottin, T.; Xu, J.; Giannis, A.; Vernos, I. ChemBioChem 2009, 10, 464-478.

4. Kappaun, S.; Sovic, T.; Stelzer, F.; Pogantsch, A.; Zojer, E.; Slugovc, C. Org. Biomol. Chem. 2006, 4, 1503-1511.

5. Achelle, S.; Rodríguez-López, J.; Guen, F.R-L. J. Org. Chem. 2014, 79, 7564-7571.

6. Kulkarni, A.P.; Tonzola, C.J.; Babel, A.; Jenekhe, S.A. Chem. Mater. 2004, 16, 4556-4573. 
7. Liu, D.; Zhang, Z.; Zhang, H.; Wang, Y. Chem. Commun. 2013, 49, 10001-10003.

8. Wilson, J.N.; Liu, W.; Brown, A.S.; Landgraf, R. Org. Biomol. Chem. 2015, 13, 5006-5011.

9. Dhuguru, J.; Liu, W.; Gonzalez, W.G.; Babinchak, W.M.; Miksovska, J.; Landgraf, R.; Wilson, J.N. J. Org. Chem. 2014, 79, 4940-4947.

10. Mphahlele, M.J.; Paumo, K.H.; El-Nahas, A.M.; El-Hendawy, M.M. Molecules 2014, 19, 795-818.

11. Paumo, K.H.; Mphahlele, M.J.; Rhyman, L.; Ramasami, P. Molecules 2015, 20, 1465614683.

12. Mphahlele, M.J.; Maluleka, M.M. Molecules 2014, 19, 17435-17463.

13. Kabri, Y.; Crozet, D.; Redon, S.; Vanelle, P. Synthesis 2014, 46, 1613-1620.

14. Kabri, Y.; Crozet, M.D.; Terme, T.; Vanelle, P. Eur. J. Org. Chem. 2015, 17, 3806-3817.

15. Grushin, V.V.; Alper, H. Chem. Rev. 1994, 94, 1047-1062.

16. Rudolph, J.; Esler, W.P.; O’Connor, S.; Coish, P.D.G.; Wickens, P.L.; Brands, M.; Bierer, D.E.; Bloomquist, B.T.; Bondar, G.; Chen, L.; Chuang, C.Y.; Claus, T.H.; Fathi, Z.; Fu, W.; Khire, U.R.; Kristie, J.A.; Liu, X.G.; Lowe, D.B.; McClure, A.C.; Michels, M.; Ortiz, A.A.; Ramsden, P.D.; Schoenleber, R.W.; Shelekhin, T.E.; Vakalopoulos, A.; Tang, W.; Wang,L.; Yi, L.; Gardell, S.J.; Livingston, J.N.; Sweet, L.J.; Bullock, W.H. J. Med. Chem. 2007, 50, $5202-5216$.

17. Waghmare, A.A.; Bose, P.; Pati, H.N. Der Pharma Chem. 2010, 2, 212-241.

18. Garcia, Y.; Schoenebeck, F.; Legault, C.Y.; Merlic, C.A.; Houk, K.N. J. Am. Chem. Soc. 2009, 131, 6632-6639.

19. Mangalagiu, I.; Benneche, T.; Undheim, K. Acta Chem. Scand. 1996, 50, 914-917. 
20. Aaron, J.J.; Tine, A.; Gaye, M.D.; Parkanyi, C.; Boniface, C.; Bieze, T.W.N. Spectrochim. Acta 1991, 47A, 419-430.

21. Diaz, A.N. Photochem. Photobiol. A 1990, 53, 141-167.

22. Yanai, T.; Tew, D.; Handy, N. Chem. Phys. Lett. 2004, 393, 51-57.

23. Frisch, M.J.; Trucks, G.W.; Schlegel, H.B.; Scuseria, G.E.; Robb, M.A.; Cheeseman, J.R.; Scalmani, G.; Barone, V.; Mennucci, B.; Petersson, G.A. et al. Gaussian 09, Revision B.01; Gaussian, Inc.: Wallingford, CT, USA 2010.

24. Cossi, M.; Barone, V.; Cammi, R.; Tomasi, J. Chem. Phys. Lett. 1996, 255, 327-335.

25. Achelle, S.; Plé, N.; Kreher, D.; Attias, A.-J.; Arfaoui, L.; Charra, F. Tetrahedron Lett. 2009, $50,7055-7058$.

26. Sunahara, H.; Urano, Y.; Kojima H.; Nagano T. J. Am. Chem. Soc. 2007, 129, 5597-5604.

27. Kaniskan, N.; Kokten, S.; Celik, I. Arkivoc 2012, Viii, 198-213. 
Synthesis, photophysical properties and DFT study of novel polycarbo-substituted quinazolines derived from the 2-aryl-6-bromo-4-chloro-8-iodoquinazolines

Hugues K. Paumo, Malose J. Mphahlele, * Lydia Rhyman and Ponnadurai Ramasami

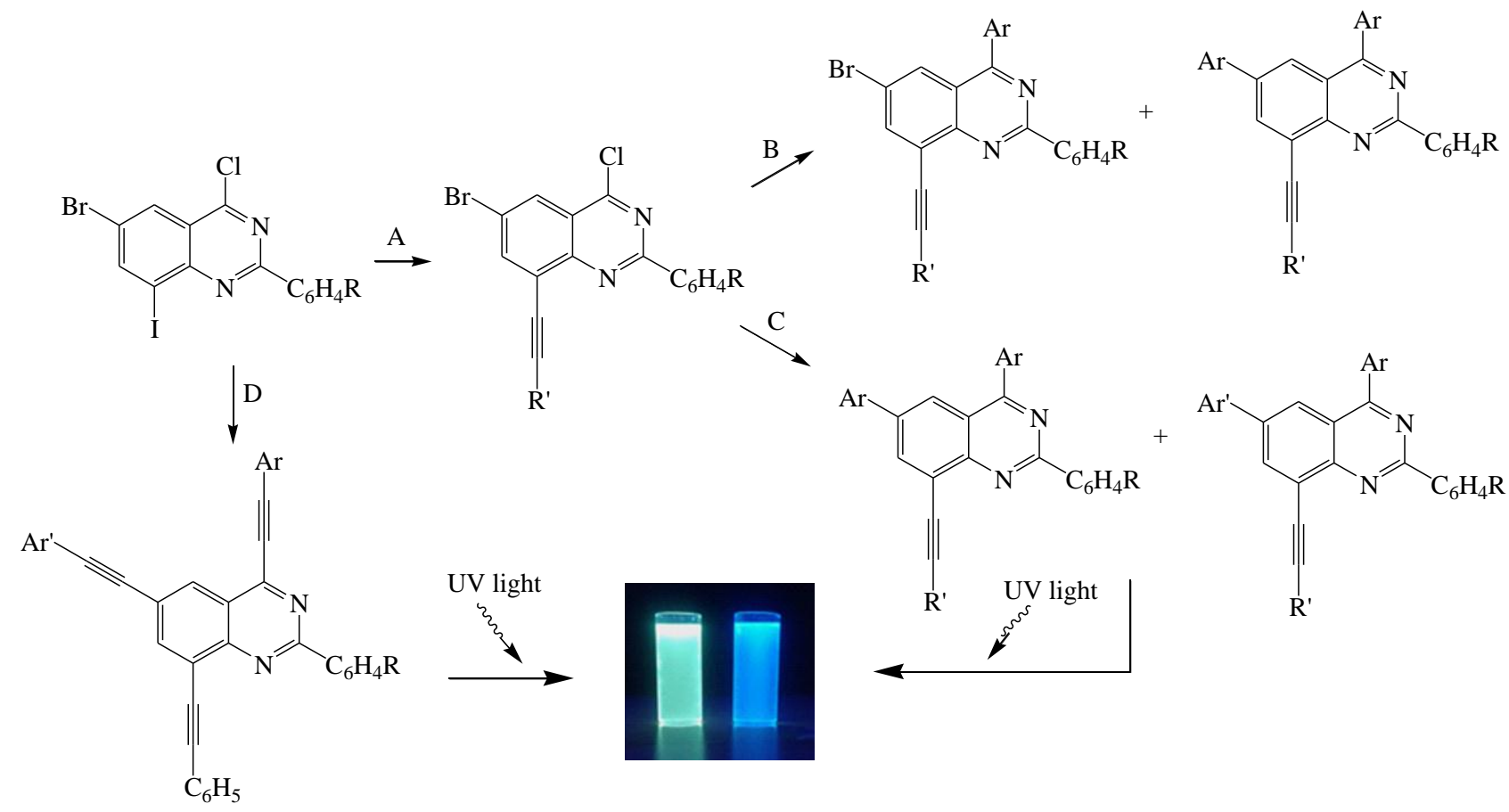

A: Sonogashira cross-coupling; B: Suzuki cross-coupling;

C: One-pot sequential Suzuki cross-coupling; D: One-pot tris-Sonogashira cross-coupling 